Макарова О. О., аспірант Одеський регіональний інститут державного управління при Президентові України Наџіональної академії державного управління м. Одеса, Україна

DOI: https://doi.org/10.30525/978-9934-26-068-1-26

\title{
ВПЛИВ ДЕРЖАВНОГО УПРАВЛІННЯ МИТНОЮ СПРАВОЮ НА ЗАХИСТ ДОВКІЛЛЯ
}

На митні органи України державою покладено важливі функції із забезпечення сприятливих умов розвитку зовнішньоекономічної діяльності. Крім цього, статтею 544 Митного кодексу України визначено, зокрема, що призначенням митних органів є забезпечення безпеки суспільства [4].

Так, у сфері управління безпекою суспільства митниця як перший державний орган, який зустрічає товари і транспортні засоби на в'їзді в Україну, покликана запобігати незаконному переміщенні товарів, заборонених або обмежених до ввезення в країну. Тому саме від ефективного та якісного виконання митницями покладених на них завдань i функцій залежить безпека життя і здоров'я громадян, стан захищеності довкілля, якість товарів, які потрапляють на внутрішній ринок.

Митним кодексом України від 13 березня 2012 № 4495-VI, зокрема в статті 319 «Взаємодія митних органів 3 іншими уповноваженими органами під час переміщення товарів через митний кордон України», визначено, що товари, які ввозяться на 
митну територію України (у тому числі 3 метою транзиту), можуть підлягати заходам офіційного контролю. Заходи офіційного контролю передбачають фітосанітарний контроль, ветеринарно-санітарний контроль, державний контроль за дотриманням законодавства про харчові продукти, корми, побічні продукти тваринного походження, здоров'я та благополуччя тварин, що проводяться згідно із законодавством України.

Вичерпний перелік товарів (з описом та кодом згідно 3 УКТ ЗЕД), які в разі ввезення на митну територію України (у тому числі з метою транзиту) підлягають заходам офіційного контролю, затверджується Кабінетом Міністрів України. Також затверджується Кабінетом Міністрів України перелік документів і відомостей, що підлягають перевірці під час здійснення попереднього документального контролю. Попередній документальний контроль полягає у проведенні в пунктах пропуску (пунктах контролю) через державний кордон України посадовими особами митних органів перевірки відповідних документів $\mathrm{i}$ відомостей, а в разі потреби, за результатами застосування автоматизованої системи управління ризиками, візуального інспектування товарів, транспортних засобів, які ввозяться на митну територію України або поміщуються в митний режим транзиту.

Попередній документальний контроль припиняється посадовою особою митного органу у разі: 1) встановленої законом вимоги щодо проведення відповідного заходу офіційного контролю відповідним уповноваженим органом; 2) ввезення на митну територію України (у тому числі з метою транзиту) живих тварин (ссавців, птахів, бджіл, комах, риб, ракоподібних, молюсків, жаб, амфібій та рептилій); 3) ввезення на митну територію України (у тому числі 3 метою транзиту) живих рослин. У разі припинення попереднього документального контролю для проведення відповідної перевірки посадовою особою митного органу невідкладно залучається посадова особа відповідного уповноваженого органу [6]. 
Окрім визначених вітчизняним законодавством нормативноправових актів із захисту довкілля та забезпечення безпеки суспільства, Україна бере на себе міжнародні зобов'язання щодо захисту флори i фауни. Так, Постанова Кабінету Міністрів України від 13.12.2000 № 1822 «Про заходи щодо забезпечення міжнародних зобов'язань України щодо іiі приєднання до міжнародної Конвенції про торгівлю видами дикої фауни та флори, що перебувають під загрозою зникнення», визначає функції митних органів України при здійсненні ними контролю видів дикої флори і фауни безпосередньо в пунктах пропуску [5].

CITES (the Convention on International Trade in Endangered Species of Wild Fauna and Flora), або Конвенція про міжнародну торгівлю видами дикої фауни і флори, що перебувають під загрозою зникнення (далі - Конвенція) - це міжнародна угода. Ïї мета - забезпечити, щоб міжнародна торгівля екземплярами диких тварин і рослин не загрожувала їх виживанню. Конвенція являє собою правову основу і визначає загальні процесуальні механізми для регулювання торгівлі перерахованими в ній видами дикої фауни і флори. Учасницями CITES є 183 країни. Це одна з природоохоронних угод із найбільшим членством. Конвенцію було підписано у Вашингтоні 3 березня 1973 року. Сьогодні CITES забезпечує різний ступінь захисту понад 37000 видів тварин і рослин, незалежно від того, чи продаються вони як живі екземпляри, хутро або сушені трави. 3 моменту, коли конвенція набрала чинності в 1975 році, жоден вид, що

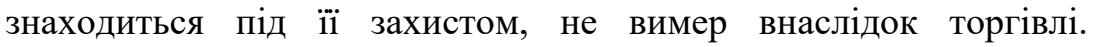
У преамбулі Конвенції зазначено, що міжнародне співробітництво є необхідним для захисту деяких видів дикої фауни та флори від їх надмірної експлуатації в міжнародній торгівлі, і держави, які приєднуються до Конвенції, переконані в нагальній необхідності вжити відповідних заходів 3 цією метою. Для визначення переліку видів, які потребують захисту, Конвенція передбачає три Додатки. Вони містять перелік видів флори i фауни, щодо яких діє ця Конвенція: від тих, які 
перебувають під загрозою зникнення, - до тих, щодо яких слід попередити чи обмежити експлуатацію.

Конвенція регламентує регулювання торгівлі зразками видів, занесених до всіх трьох Додатків. Так, для експорту, імпорту, реекспорту будь-якого зразка таких видів необхідна попередня видача та пред'явлення дозволу - відповідно на експорт, імпорт, реекспорт. Такий дозвіл видається лише якщо: (а) науковий орган держави зробив висновок, що це не загрожує виживанню цього виду; (b) адміністративний орган держави, переконався в тому, що зразок був придбаний без порушення законів держави щодо захисту фауни та флори, а також транспортується належним чином.

Україна стала учасницею CITES 14 травня 1999 року, коли Верховна Рада ратифікувала Угоду про приєднання до Конвенції про міжнародну торгівлю вимираючими видами дикої фауни та флори (CITES). Функції контролю об'єктів CITES в пунктах пропуску через митний кордон України з 2018 року виконує Держмитслужба [2].

Окрім заходів, передбачених Конвенцією CITES, Державна митна служба України активно бере участь в інших міжнародних програмах із захисту довкілля.

Представники Держмитслужби отримали право використовувати електронну базу даних Європейського Союзу EU-TWIX (Свропейський обмін інформацією про торгівлю дикою природою). База даних EU-TWIX була розроблена для надання допомоги національним правоохоронним органам щодо виявлення, аналізу та моніторингу незаконної діяльності, пов'язаної 3 торгівлею фауною та флорою. Крім того, у ньому $є$ розділ 3 інформацією про технічні, наукові, економічні та інші галузі, які допоможуть в ідентифікації, оцінці, утилізації тощо вилучених або конфіскованих зразків [3].

За сприяння Всесвітнього фонду природи WWF, Державна митна служба України долучилася до всеєвропейської системи EU TWIX (The European Union Trade in Wildlife Information eXchange - EU-TWIX), у якій відбувається обмін інформацією 3 
торгівлі видами дикої природи в Європейському Союзі. Завдяки цьому інструменту українські та європейські митники отримали можливість обмінюватися експертизою та відповідною оперативною інформацією [1].

Таким чином, чітке визначення функцій митних органів України та надання їм відповідних повноважень 3 митного контролю товарів, різних видів флори і фауни, належний контроль за виконанням покладених на них функцій 3 боку державних контролюючих органів має забезпечити захист довкілля не тільки України, а і країн - торговельних партнерів. В разі незабезпечення митними органами безпекової функції це може призвести не тільки до розповсюдження неякісної продукції, хвороб, інфекцій, а і зруйнувати певні екосистеми шляхом порушення їх природного балансу. Тому нехтування безпековими функціями в митній справі заради зосередження лише на фіскальній складовій діяльності митних органів в довгостроковій перспективі може мати більш згубні наслідки для наших нащадків.

\section{Література:}

1. Офіційний сайт Всесвітній фонд природи - Україна. URL: https://wwf.ua/our-work/wildlife/wildlife-crime-prosecution/?.

2. Офіційний сайт CITES. URL: https://cites.org.

3. Офіційний сайт EU TWIX. URL: https://www.eu-twix.org/members.

4. Митний кодекс України. URL: https://zakon.rada.gov.ua/laws/show/449517\#Text.

5. Офіційний сайт Верховної Ради України. URL: https://zakon.rada.gov.ua/ laws/show/1822-2000-п\#Text.

6. Офіційний сайт Державної митної служби України. URL: https://customs.gov.ua/news?news. 